\title{
Characterization of a Massive Sandstone Interval: Example From Doko Member of Bida Formation, Northern Bida Basin, Nigeria
}

\author{
Goro A.I. ${ }^{1, *}$, Salihu H.D. ${ }^{1}$, Jibrin B.W. ${ }^{2}$, Waziri N.M. ${ }^{1}$, Idris-Nda A. ${ }^{1}$ \\ ${ }^{1}$ Department of Geology, Federal University of Technology, P.M.B. 65, Minna, Nigeria \\ ${ }^{2}$ Department of Geology and Mining, Ibrahim Badamasi Babangida University, Lapai, Nigeria \\ *Corresponding Author: isahgoro@futminna.edu.ng
}

Copyright () 2014 Horizon Research Publishing All rights reserved.

\begin{abstract}
A field mapping and laboratory study was undertaken to characterize the lower portion of Bida Formation around Jima and Doko areas near Bida, central Nigeria. Field mapping revealed four lithofacies for the sandy braided river deposits. They are: (1) lithofacies Fa consists of gravely, very coarse sandstones; (2) lithofacies $\mathrm{Fb}$ is characterized by gravely, medium to very coarse grained sandstones; (3) lithofacies Fc is identified by coarse silt to fine grained sandstones; (4) lithofacies $\mathrm{Fd}$ is recognized by sheet-like beds of fine to medium grained sandstones. They record channel flow (Fa), subaqueous dune $(\mathrm{Fb})$, overbank $(\mathrm{Fc})$ and crevasse splay deposits $(\mathrm{Fd})$ respectively. The four lithofacies allowed the definition of two architectural elements: (1) channel architectural element (CH) and (2) overbank architectural element (OF). A $\mathrm{CH}$ element overlain by an OF element defines a unit bar; while stacked, multiple $\mathrm{CH}$ overlain by an $\mathrm{OF}$ delineate a compound bar. Computation of grain size data for $\mathrm{Fa}$ and $\mathrm{Fb}$ facies yielded permeability values of 19.4 to 352.3 millidarcies using empirically generated equation. Because permeability values do not vary much, it is suggested that $\mathrm{Fa}$ and $\mathrm{Fb}$ be treated as one homogeneous entity if object based reservoir modelling of the sandstones is to be done. This work shows that detailed field mapping integrated with grain size data can offer valuable information useful for aquifer and reservoir studies of the sandstones.
\end{abstract}

Keywords Sandstones, Architectural Element, Reservoir, Fluvial, Channel

\section{Introduction}

The distinction between single and stacked channel floor, channel bar and overbank units in fluvial successions is key to understanding the dynamics of fluid flow within them. Fluvial sandstones and conglomerates represent important hydrocarbon reservoirs and water aquifers the world over. In order to understand better the internal and external geometry of the sandstones which has implications for withdrawal of fluid from them; a lot of attempts have been made to understand the character of both modern and ancient fluvial deposits using outcrop data. These studies have been used to better constrain sub-surface successions.

The present work attempts to characterize the structureless sandstone units of Doko Member of Bida Formation [1], exposed around Jima and Doko near Bida city, Nigeria. This is important because the sediments serve as aquifer in this region; in addition to being potential reservoir rocks at deeper levels. Even though scattered outcrops occur in streams around Bida, a good understanding of these sediments is possible in areas around Doko and Jima where mesas of different dimensions allow their study. Earlier works on characterization of the sediments of Bida basin concentrated on the southern part [e.g. 2, 3], but the laterally equivalent succession in the northern part is yet to be studied in detail.

The main aim of this work is to characterize the massive sandstone units forming the lower to middle portion of Bida Formation exposed around Bida. Major objectives include identification of facies and facies associations within the interval and to interpret them in terms of architectural elements of Mial $[4,5]$. Criteria for identification of unit and compound bars were also defined. Grain size distribution data was obtained by particle size analysis. The data was used to compute permeabilities of the sediments using empirically derived formula that relates grain size to permeability.

\section{Location and Geological Setting}

The study area is situated near the central part of Bida basin, a major inland sedimentary basin in Nigeria (Fig. 1). The Bida basin is a NW-SE trending structure which extends from Kontagora in the northern sector to Lokoja in the southern one covering a distance of about $400 \mathrm{~km}$. It has a sedimentary fill of up to $4.7 \mathrm{~km}$ with an average of $3 \mathrm{~km}$ [6]. 


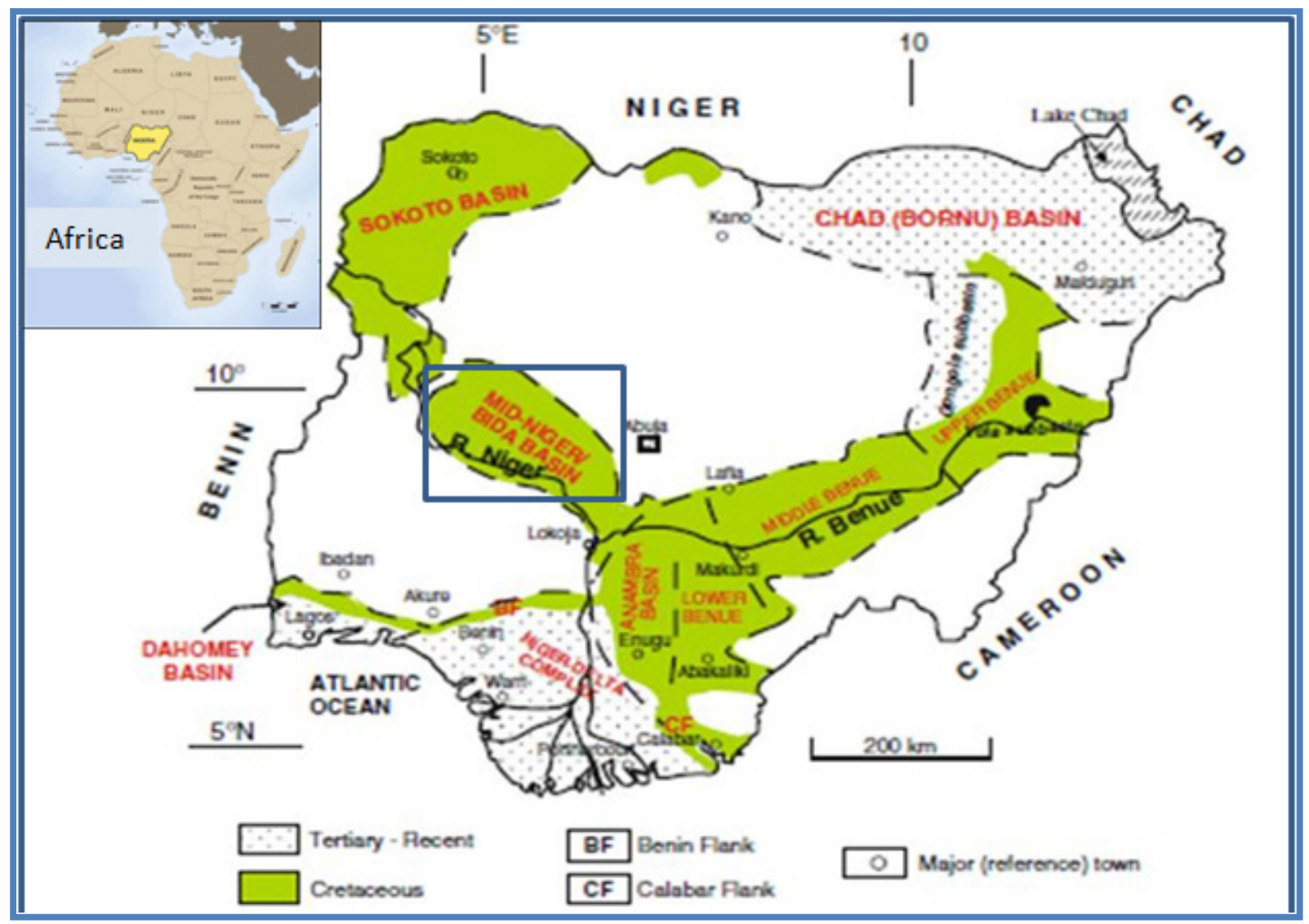

Figure 1. Map pf Nigera showing the position of Bida Basin (from Obaje,2009)

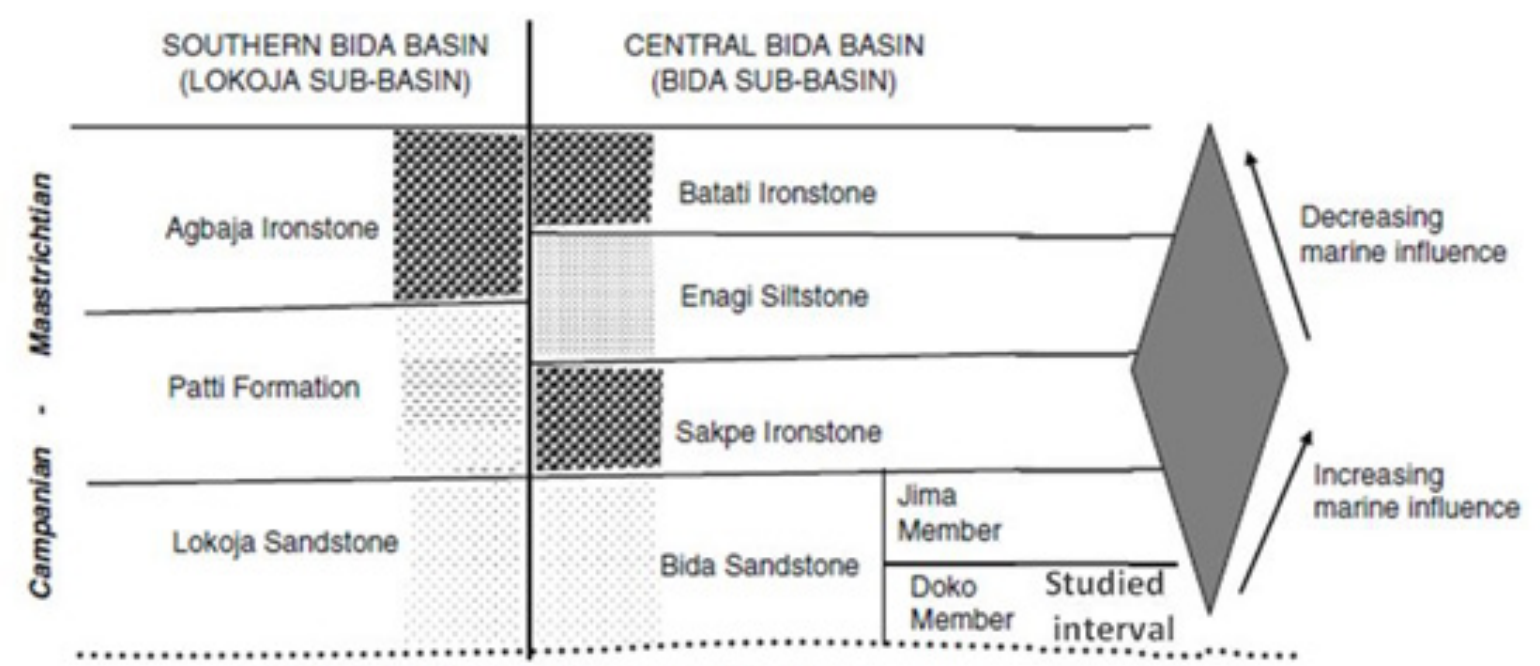

PRECAMBRIAN BASEMENT

Figure 2. Stratigraphic successions in the Bida Basin (modified from Obaje,2009)

Adeleye [1] identified four lithostratigraphic successions in the northern part of the basin (Fig. 2). At the base is Bida Formation consisting of massive gravelly, coarse to very coarse sandstones of Doko Member overlain by fine to medium grained cross bedded sandstones and mudstones of Jima Member.

They were inferred to be deposited in braided and meandering river systems. Sapke Formation overlies the Bida Formation and consists of mainly ironstone with geothite. Enagi Formation comprises mainly siltstones, mudstones and very fine sandstones deposited in distal fan, flood plain and lacustrine environments; it is overlain by Batati Formation consisting mainly of ironstones with geothite and kaolinite. 


\section{Methodology}

Four lithological logs of fairly exposed parts of a mesa around Jima village were constructed giving accounts of lithology, colour, textures and structures as well as thickness of the beds. Facies analyses as well as architectural element concept were used to characterize the various aspects of the sediments to infer their origin.

A total of twenty six representative sandstone samples were subjected to sieve analysis to obtain the grain size parameters which were used to empirically compute their permeabilities using Krumbein and Monk [7] formula:

$$
\mathrm{K}=\mathrm{CoDm}^{2} \mathrm{e}^{-1.31 \sigma}
$$

where $\mathrm{K}=$ intrinsic permeability (Darcies), $\mathrm{Co}=$ an empirical constant $\left(760\right.$ Darcies $\left./ \mathrm{mm}^{2}\right), \mathrm{Dm}=$ median diameter $(\mathrm{mm})$ and $\sigma=$ sorting (in phi standard deviation). Median grain diameter is used due to generally poor sorting and well skewed grain size distribution of the sediments.

Mathematical relationships for estimating permeability using particle size have been developed and well known in the literature. Most formulas see permeability as a function of just one rock property such as mean grain size or porosity. However, the work of Krumbein and Monk [7] was more detailed and considered permeability as a function of both grain size and sorting for a given porosity. Though their experiment was performed sand packs at a constant porosity of $40 \%$, and the equation did not take account of porosity as a parameter, it was established by later works [e.g. 8] to fit well for samples with porosities between 23 to $43 \%$. The use of empirical formula to estimate permeability in this work is necessitated by lack of adequate laboratory equipment as well as unavailability of core or geophysical well log data in the study area. However, studies have shown that they provide good estimates that have been used for reservoir characterization, geotechnical analysis and groundwater flow simulation studies [e.g. 9].

Because the sandstones are friable, porosity measurement was done using the formula of Lambe [10] which relates porosity to bulk and particle density of the rock. Consistent porosity results were obtained for laterally equivalent sandstones [3] using this method. The equation is given as:

$$
\mathrm{n}=100\left(1-\rho_{\mathrm{b}} \rho_{\mathrm{p}}{ }^{-1}\right)
$$

where $\mathrm{n}=$ total porosity $(\%) ; \rho_{\mathrm{b}}=$ total density of the material $\left(\mathrm{gcm}^{3}\right) ; \rho_{\mathrm{p}}=$ particle density of the material $\left(\mathrm{gcm}^{3}\right)$. A particle density of $2.65 \mathrm{~g} / \mathrm{cm}^{3}$ [after Fetter, 11] was used since the bulk of the sandstone is composed of silica. The total density was calculated by dividing total mass of oven dried rock sample by the total volume of the sample. The volume was obtained using water displacement test.

The percentage of sand, silt and clay fractions in the sandstones as revealed by sieve analysis is plotted on triangular diagram to further characterize them into textural classes.

\section{Results and Interpretation}

Four main lithofacies have been identified and they can be related to lithofacies codes and architectural elements of Mial $[12,4]$. All the identified facies display varying degrees of colour mottles.

\subsection{Lithofacies Fa - Sandy Conglomerate Facies}

The facies consists of very coarse sandstones with gravel components of above $15 \%$. Only a few samples comprise more than $30 \%$ gravel. The sediments are commonly 20 - 40 $\mathrm{cm}$ thick and overlie erosional basal contacts (Fig. 3B, C, F, G). Mud rip up clasts are present in some units. The sediments of this facies make up about $10 \%$ of the studied interval (Fig. 3). They often overlie lithofacies Fc or Fd (Fig. 3C, F, G), but may occasionally overlie Fb (Fig. 3B). The sediments are always overlain by $\mathrm{Fb}$.

\subsection{Lithofacies Fb - Medium to Coarse Grained Sandstones}

This facies consists of $1.7-5 \mathrm{~m}$ thick gravely, medium grained sandstones, gravely coarse grained sandstones, coarse grained sandstones and subordinate medium grained sandstones. Gravelly coarse grained sandstones predominate making up about $70 \%$ of the facies (Table 1). Gravel component is generally between 2 and $6 \%$ but rises to as high as $17 \%$ in some samples. They usually overlie $\mathrm{Fa}$ sediments with sharp or sometimes gradational contact (Fig. $3 F, G)$. Some unit show fining upwards trend, whereas others appear homogeneous with scattered gravels. Trough cross bedding are seldom observed locally. The sediments are usually overlain by Fc facies (Fig. 3E, G) but may be truncated by Fa facies (Fig 3B).

\subsection{Lithofacies Fc - Siltstone Facies}

The facies consists of moderately well sorted, massive, coarse siltstones to muddy very fine grained sandstones. These sediments display purple or sometimes light brown colour (Fig. 3C, G). They usually overlie the Fb sediments with sharp planar contact (Fig. 3E, G). The upper boundaries are sharp and erosional (Fig. 3C, E F G). The sediments may pinch out laterally within a few meters (Fig. 3G) and are 0.5 to $2 \mathrm{~m}$ thick. Sheet-like beds of fine to medium grained sandstones (Fd facies) may occur within them (Fig. 3E; Fig. $4, \log 3)$. 


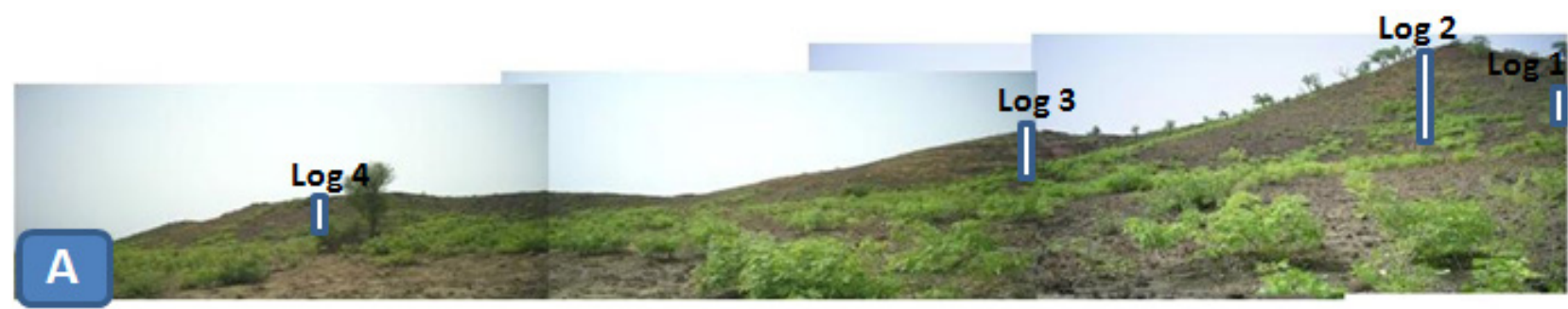

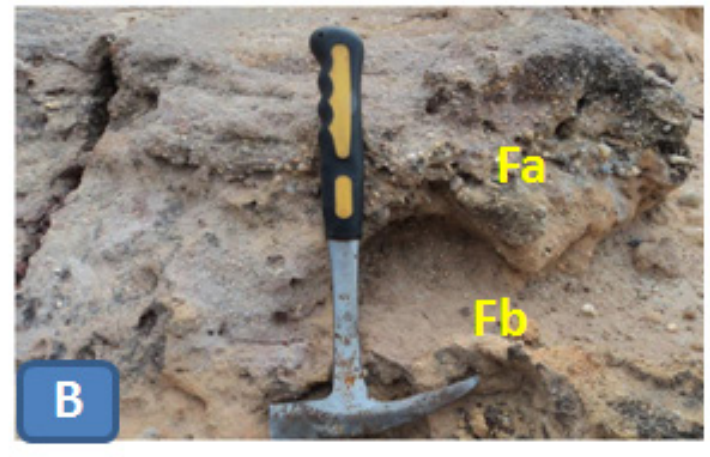
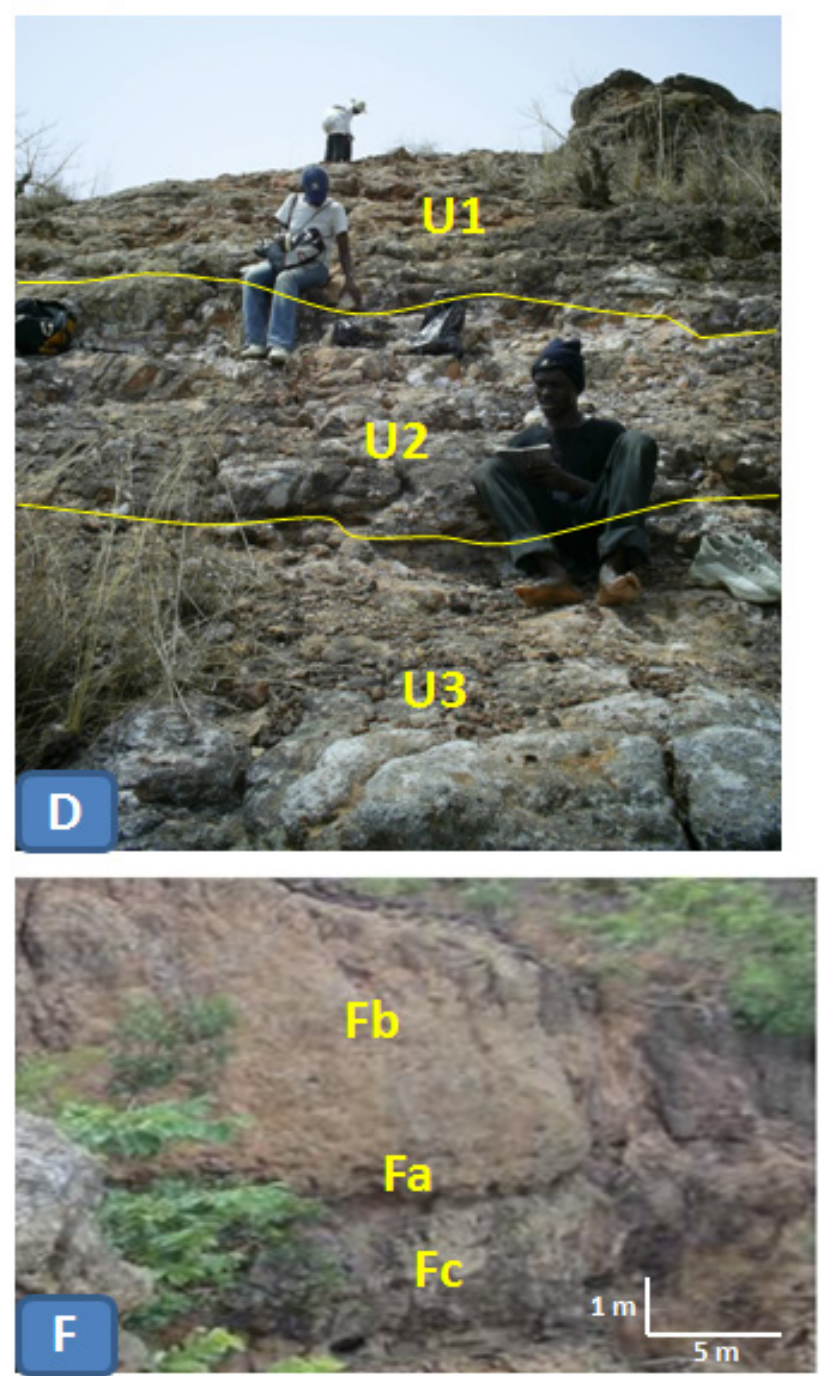
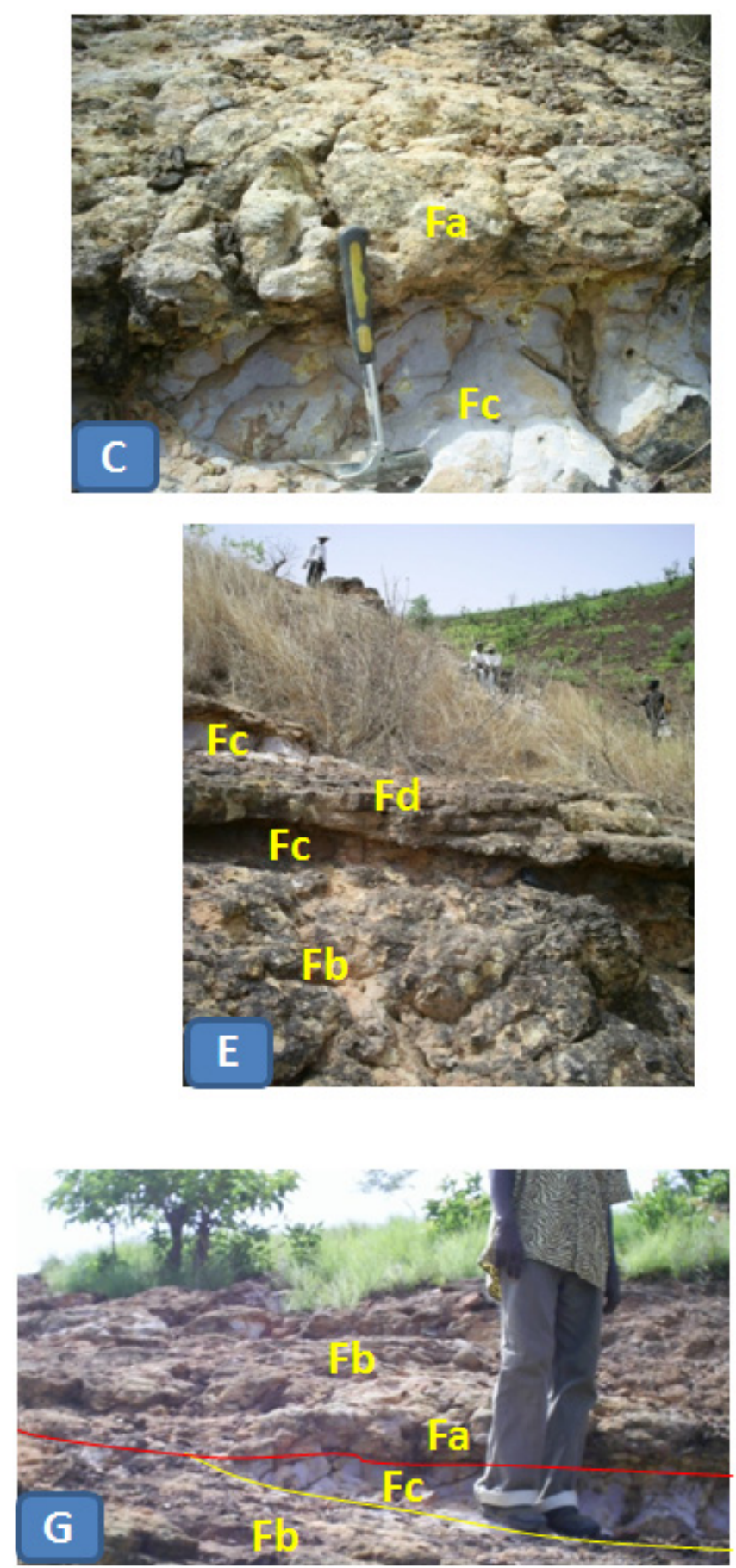

Figure 3. Outcrop pictures showing: (A) location of logged areas near Jima village; (B) Fa overlying Fb facies; (C) Fa overlying Fb facies, note the purple colour of Fc facies; (D) three unit bars U1, U2\&U3; (E) Fb overlain by Fc, note the position of FD within Fc; (F) sheet like geometry of the sandstones; $(\mathrm{G})$ lateral pinch-out of $\mathrm{Fc}$ facies 
Table 1. Textural parameters and estimated permeabilities of parts of the Maastritchian Doko Member of Bida Formation, Bida Basin, Nigeria

\begin{tabular}{|c|c|c|c|c|c|c|c|c|}
\hline $\begin{array}{l}\text { Sample } \\
\text { No. }\end{array}$ & Facies & $\begin{array}{l}\text { Sorting } \\
\text { (Phi) }\end{array}$ & $\begin{array}{c}\text { Median } \\
\text { grain size } \\
\text { diameter } \\
(\mathrm{mm})\end{array}$ & Grain size & Textural Class & Skewness & $\begin{array}{c}\text { Porosity } \\
\text { (\%) }\end{array}$ & $\begin{array}{l}\text { Permeability } \\
\text { (millidarcies) }\end{array}$ \\
\hline 1 & $\mathrm{Fa}$ & 1.4 & 1.71 & Very coarse & Sandy Conglomerate & Strongly Fine Skewed & 48 & 352.3 \\
\hline 2 & $\mathrm{Fb}$ & 1.5 & 0.71 & Coarse & Sandstone & Fine Skewed & - & 53.8 \\
\hline 3 & $\mathrm{Fb}$ & 1.5 & 0.57 & Coarse & Gravely Sandstone & $\begin{array}{l}\text { Strongly Coarse } \\
\text { Skewed }\end{array}$ & - & 35.4 \\
\hline 4 & $\mathrm{Fb}$ & 1.4 & 0.62 & Coarse & Gravely Sandstone & $\begin{array}{c}\text { Strongly Coarse } \\
\text { Skewed }\end{array}$ & 37 & 47.1 \\
\hline 5 & $\mathrm{Fb}$ & 1.4 & 0.41 & Medium & Sandstone & $\begin{array}{c}\text { Strongly Coarse } \\
\text { Skewed }\end{array}$ & 27 & 19.6 \\
\hline 6 & $\mathrm{Fb}$ & 1.2 & 0.81 & Coarse & Gravely Sandstone & Fine Skewed & - & 106.7 \\
\hline 7 & $\mathrm{Fb}$ & 1 & 0.66 & Coarse & Gravely Sandstone & Strongly Fine Skewed & - & 94.0 \\
\hline 8 & $\mathrm{Fb}$ & 1.1 & 0.44 & Medium & Gravely Sandstone & $\begin{array}{l}\text { Strongly Coarse } \\
\text { Skewed }\end{array}$ & 40 & 35.8 \\
\hline 19 & $\mathrm{Fb}$ & 1.6 & 0.47 & Medium & Gravely Sandstone & $\begin{array}{l}\text { Strongly Coarse } \\
\text { Skewed }\end{array}$ & - & 20.3 \\
\hline 10 & $\mathrm{Fb}$ & 1.1 & 0.76 & Coarse & Sandstone & Strongly Fine Skewed & - & 109.9 \\
\hline 11 & $\mathrm{Fb}$ & 1.3 & 1.19 & Very coarse & Sandstone & Strongly Fine Skewed & - & 201.9 \\
\hline 12 & $\mathrm{Fb}$ & 1.2 & 0.62 & Coarse & Gravely Sandstone & Strongly Fine Skewed & - & 57.1 \\
\hline 13 & $\mathrm{Fa}$ & 1.2 & 0.66 & Coarse & Gravely Sandstone & Strongly Fine Skewed & - & 70.0 \\
\hline 14 & $\mathrm{Fb}$ & 1.4 & 0.81 & Coarse & Gravely Sandstone & Strongly fine skewed & - & 79.3 \\
\hline 15 & $\mathrm{Fb}$ & 1.3 & 0.57 & Coarse & Sandstone & Strongly coarse skewed & - & 48.0 \\
\hline 16 & $\mathrm{Fb}$ & 1.3 & 0.87 & Coarse & Gravely Sandstone & Strongly fine skewed & - & 104.9 \\
\hline 17 & $\mathrm{Fa}$ & 1.2 & 0.62 & Coarse & Gravely Sandstone & coarse skewed & - & 57.8 \\
\hline 18 & $\mathrm{Fb}$ & 1.2 & 0.47 & Medium & Gravely Sandstone & Strongly coarse skewed & - & 36.4 \\
\hline 19 & $\mathrm{Fb}$ & 1.5 & 0.44 & Medium & Gravely Sandstone & Strongly coarse skewed & - & 19.4 \\
\hline 20 & $\mathrm{Fb}$ & 1.1 & 0.44 & Medium & Sandstone & Strongly coarse skewed & - & 34.5 \\
\hline 21 & $\mathrm{Fa}$ & 1.5 & 1.19 & Very coarse & Sandy conglomerate & Strongly fine skewed & 43 & 152.6 \\
\hline 22 & $\mathrm{Fb}$ & 1.7 & 1.11 & Very coarse & Gravely Sandstone & Strongly fine skewed & 43 & 105.0 \\
\hline 23 & $\mathrm{Fb}$ & 1.3 & 0.5 & Coarse & Gravely Sandstone & Strongly coarse skewed & - & 36.2 \\
\hline 24 & $\mathrm{Fb}$ & 0.8 & 0.47 & Medium & Sandstone & Strongly fine skewed & 37 & 56.9 \\
\hline 25 & $\mathrm{Fb}$ & 1.4 & 0.5 & Coarse & Sandstone & Strongly coarse skewed & - & 31.1 \\
\hline 26 & $\mathrm{Fb}$ & 1.6 & 0.57 & Coarse & Gravely Sandstone & Strongly coarse skewed & 29 & 32.4 \\
\hline
\end{tabular}



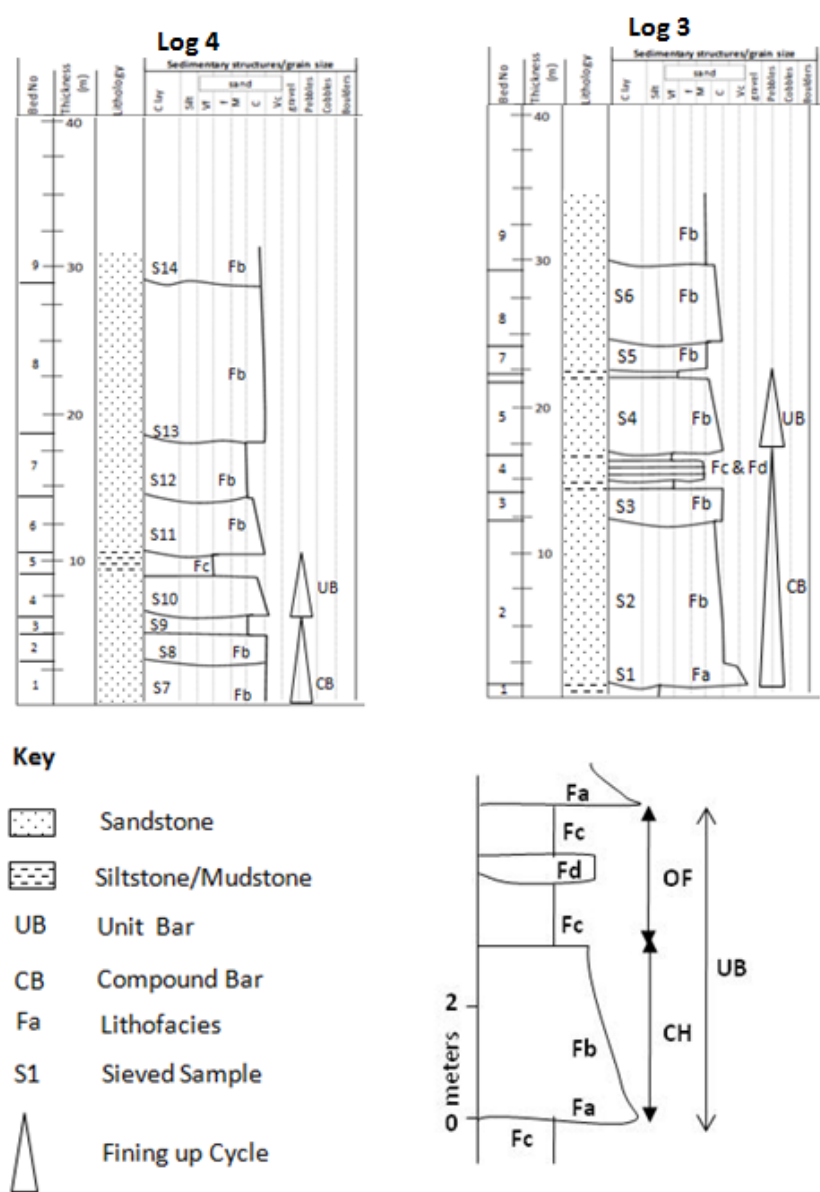
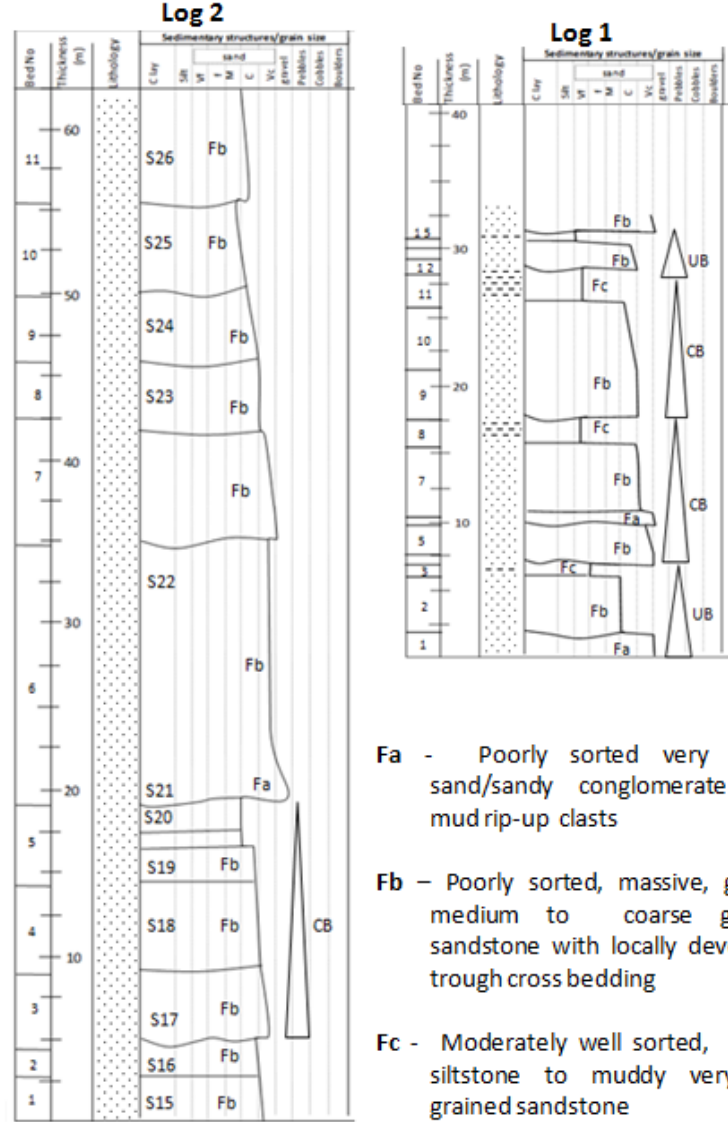

Fa - Poorly sorted very coarse sand/sandy conglomerate with mud rip-up clasts

Fb - Poorly sorted, massive, gravely medium to coarse grained sandstone with locally developed trough cross bedding

Fc - Moderately well sorted, coarse siltstone to muddy very fine grained sandstone

Fd - Tabular fine to medium grained sandstone

Figure 4. Sedimentological lops of outcrops around Jima village (Log 1-4) and model representing a complete unit bar with its division into lithofacies and architectural elements.

\subsection{Lithofacies Fd - Fine to Medium Grained Sandstone Facies}

This facies consists of fine to medium grained sandstones (with scattered coarse to pebble sized particles). They have tabular geometry and occur within Fc sediments (Fig. 3E). They often have flat tops and irregular lower surfaces and appear more resistant to erosion compared to the $\mathrm{Fc}$ sediments (Fig. 3E; Fig. 4, $\log 3$ ). They are typically $5-20$ $\mathrm{cm}$ thick. Two to four beds may join up to make $30-70 \mathrm{~cm}$ thick units (Fig. 3E).

\subsection{Processes and Environment Interpretation}

The sediments of $\mathrm{Fa}$ display typical features of $\mathrm{Gm}$ lithofacies code of Mial $[12,4]$ which is interpreted as basal gravels recording traction deposits in the deepest part of channels [9, 10]. The $\mathrm{Fb}$ facies is here assigned $\mathrm{Sm}$ lithofacies code, although not presented by Mial, it has been used by researchers in this field [e.g. 15] to represent massive sandstone units with dimensions similar to the St and Sp lithofacies code of Mial. The massive nature has been inferred to be due to destruction of primary stratification by bioturbation processes or rapid sedimentation disallowing formation of primary internal layering. Some longitudinal bars are also known to display massive to crude bedding $[4,5$, $16,17]$. They are inferred to be deposited due to lower flow regime, sub-aqueous migration of $2 \mathrm{D}$ or $3 \mathrm{D}$ dunes $[5,13]$.

The Fc sediments corroborate Fl or Fm lithofacies code of Mial $[12,4]$ which represents overbank or waning flow deposits. The texture and geometry of $\mathrm{Fd}$ favours its interpretation as Ss lithofacies code of Mial [4], it records the fill of a broad shallow scour within a flood plain environment.

\subsection{Architectural Element Analysis}

The lithofacies have been grouped into two architectural elements (based on their vertical profile as well as internal and external geometry/form): 1) channel architectural element $(\mathrm{CH})$ composed of $\mathrm{Fa}$ and $\mathrm{Fb}$; and 2) overbank architectural element (OF) consisting of Fc and Fd. The channel fill element consists mainly of massive (locally cross bedded) medium to very coarse often gravely sandstones of $\mathrm{Fb}$ with associated gravely sandstones and conglomerates of $\mathrm{Fa}$ at the base. The basal boundary is a concave up erosional boundary and the upper boundary may be sharp or gradational (Fig. 3, 4). The OF element is characterised by siltstones $(\mathrm{Fc})$ and the associated fine to medium grained 
sandstones $(\mathrm{Fd})$ that occur within them. The element is typically $1-3 \mathrm{~m}$ thick with a sheet-like geometry, indicative of vertical aggradation [5]. The lower boundary is slightly concave up while the upper boundary is usually a truncation surface by the basal boundary of the channel element. It may show upward fining or coarsening of grain size depending on the amount of relief at the upper erosional contact. Fd sediments may be products of crevasse channels or bar top channels. Their deposition is usually facilitated by high water stages (bank full) [5].

Field relations show that a single fining upward unit that is $1-5 \mathrm{~m}$ thick is formed by a single $\mathrm{CH}$ element overlain by an OF element, but where multiple $\mathrm{CH}$ elements are stacked below an $\mathrm{OF}$ element, then a composite fining upwards unit that is $5-15 \mathrm{~m}$ thick is formed. This arrangement gives the sediments an interbedded attitude at outcrop scale.

\subsection{Grain Size Distribution and Permeabilities}

Only $\mathrm{Fa}$ and $\mathrm{Fb}$ were sampled for permeability computation owing to their attitude as either aquifers or hydrocarbon reservoirs. The grain size parameters as well as empirically determined permeabilities (Table 1) show that the $\mathrm{Fa}$ and $\mathrm{Fb}$ sediments do not vary much.

The grain sizes are between medium and very coarse with about $60 \%$ being coarse grained; $30 \%$, medium grained and
$10 \%$ very coarse grained sandstones. They are generally poorly sorted and dominantly strongly coarse or fine skewed. Classification based on percentage of sand, silt and gravel fractions show that they are about $70 \%$ gravely sandstones with a few samples plotting within the pure sandstone field (figure 5). Only one sample had gravel greater than $30 \%$, hence sandy conglomerate (Figure 4). Based on few selected samples, porosity values ranged between $27 \%$ and $48 \%$ with an average of $38 \%$. Handling the samples was difficult due to their friable nature; as a result the measurements were not checked using alternative method. This method, however gave consistent results in laterally analogous units in the southern part of the basin [3]. Permeabilities range from 19.4 to 352.3 millidarcies with average of 76.9 millidarcies. At least $65 \%$ of permeability values fall within 19 and $100 \mathrm{mD}$. Compared with global trend in the relationship between sandstone reservoir porosities and permeabilities, these values are expected to decrease with depth unless if perhaps they are increased by fractures or such diagenetic processes as grain/cement dissolution [18]. Even though the highest permeabilty value was recorded by a sandy conglomerate of $\mathrm{Fa}$, it is observed that there is no any significant difference between $\mathrm{Fa}$ and $\mathrm{Fb}$ values obtained for the rest of the sediments.

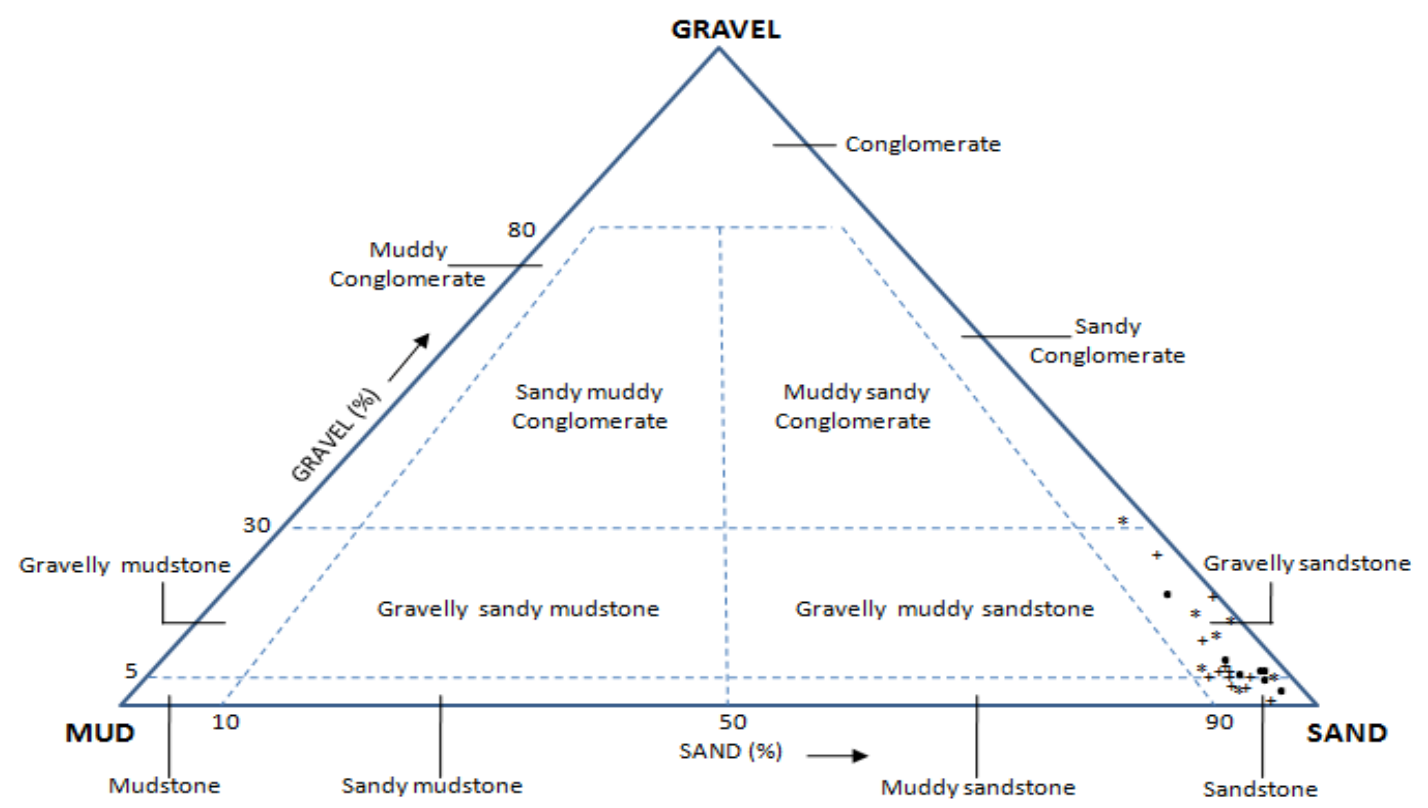

Figure 5. Scheme for classifying sand-gravel-mud mixtures and terms for rock (modified from Udden-Wentworth and Blair \&McPherson, 1999).

Note: Samples from $* \log 2, * \log 3, * \log 4$ 


\section{Discussion}

\subsection{Depositional and Facies Architecture}

Recent understanding of sandy braided river deposits of modern Saschachewan River based on aerial photos and GPR data sets [e.g 19,20] reveals that they are made up mainly of unit and compound bars with the unit bars divisible in to lower and upper bar portions [21]. The studied sediments show typical features of sandy braided river channel deposits described by these authors as well as Cant and Walker [22] whose model has been adopted as typical [8, 19] and more recently [20]. The single fining up $\mathrm{CH}$ plus overlying OF elements of the present work constitute the lower and upper bar portions of unit bars while the composite fining up units formed from stacked $\mathrm{CH}$ elements with the overlying OF element are the compound bars. Smith [23] defined unit bars as having a non amalgamated/stacked form whose shape are maintained during migration. Compound bars on the other hand are defined by Bridge [24] as bar forms that comprise more than one unit bar due to recurring erosional and deposition events [19]. The fining upwards recorded from the base to the top of a unit bar represent lateral facies change from higher energy deeper parts of channels to low energy overbank parts.

Interpretation of these massive sandstone units as braided river deposits was made by earlier workers [1, 25, 24, 27]. The Fa facies of this work correspond to the breccia facies of [25] while the $\mathrm{Fb}$ and $\mathrm{Fc}$ facies of this work show typical features of sandstone facies and argillaceous facies of [25] respectively. Similar massive sandstone units with braided river origin are well documented in the literature [e.g. 28, 29] where the structureless nature was interpreted as due to rapid deposition [29] or as a result of biogenic reworking [15]. The later interpretation is possible in these sediments owing to the presence of colour mottling indicating bioturbation within the study area. The lower part of Bluejacket sandstone in Eufaula Dam area (U.S.A) contains similar massive sandstones of braided river origin directly overlain by internally cross bedded sandstones [28]; similar to the relationship between the Doko (massive) and Jima (cross bedded) sandstones of Bida basin. Studies involving many data sets of some the thickest braided river sediments show that they are deposited during periods of active tectonic phase, rapid subsidence, accompanied by enhanced coarse sediment flux [30]. The generally coarse nature of the sediments can be explained by factors such as proximity to source area in addition to high energy conditions of the depositional environment.

\subsection{Implication for Reservoir Studies}

Accurate identification of these facies and architectural elements has great implication for ground water and petroleum reservoir studies in this basin. Lateral connectivity is expected to be good due to the sheet geometry (Fig. 4F) of the sandstones afforded by the extensive lateral migration and channel aggradation [17]. The laterally restricted nature of the OF element preclude the formation of stratigraphic traps in the studied interval. Vertical permeabilities are expected to be good especially in stacked compound bars but the overlying OF elements may produce low permeability zones within the sediments.

Similar attributes displayed by channel fill $(\mathrm{Fa})$ and bar deposits $(\mathrm{Fb})$ shows that they can be treated as one permeability zone in aquifer or reservoir modeling/simulation studies of the sandstones. Ashwort et al. [31] also made a similar conclusion on the sandy braided river deposits of the Sascatchewan River USA. Identification of some complete unit and compound bars can be used to infer bank full depths in the paleoenvironment. For example the average thickness of the most complete unit bars range from 2.1-5.5 m with mean of $4.3 \mathrm{~m}$; compound bars range in thickness from 7.6-15 $\mathrm{m}$ with average of $11.6 \mathrm{~m}$.

\section{Conclusions}

Field analyses have shown that the massive lower portion of Bida Formation in the Bida Basin, Central Nigeria is a complex that is made up of many smaller, erosionally based bodies. These bodies comprise unit and compound bars that are laterally and vertically stacked giving a sheet-like geometry. Two architectural elements mainly channel $(\mathrm{CH})$ and overbank (OF) are typical. The braided character of the fluvial deposits has been infered from facies and facies architectural elements analyses. There is little difference in grain size as well as permeabilities of channel floor and bar deposits in this area, which suggests that both facies can be treated uniformly in object based reservoir modelling of the sandstones.

It is important to note that as with other techniques used in characterisation of sediments, permeability estimates using grain size data has its limitations. This work, however, provides first hand information in a relatively unexplored basin where no deep well or core data is available. Other factors such as diagenesis, that greatly influence permeability and porosity of sandstones are topics that are suggested for further studies.

Nonetheless, this study demonstrate that field mapping combined with grain size analysis of these sediments has some value in understanding the Maastritchian braided river system of Bida Basin. With the growing population and consequent high demand for ground water in the region in addition to prospects of the presence of hydrocarbons in the basin; this study has implications for reservoir and aquifer potentials of the rocks as well as insights that may perhaps help in furthering our understanding of the regional geology of the area. 


\section{REFERENCES}

[1] Adeleye D. R. Stratigraphy and Sedimentation of the Upper Cretaceous Strata around Bida Nigeria, Ph.D thesis, University of Ibadan, 1972.

[2] Ojo, O. J. and Akande, S. O. Sedimentology and depositional environments of the Mastrichtian Patti Formation, southeastern Bida Basin, Nigeria, Cretaceous Research, Vol. 30, 1415-1425, 2009.

[3] Vrbka, P., Ojo, O. J. and Gebhardt, H. Hydraulic characteristics of the Maastrichtian sedimentary rocks of the southern Bida Basin, central Nigeria, Journal of African Earth Sciences. Vol. 29, No. 4, 659-667, 1999.

[4] Miall, A. D. Architectural-element analysis: A new method of facies analysis applied to fluvial deposits, Earth Science Reviews, Vol. 22, No. 25, 261-308, 1985.

[5] Miall, A. D. Architectural elements and bounding surfaces in fluvial deposits: anatomy of the Kagenta Formation (Lower Jurasssic), southwest Colorado, Sedimentary Geology, Vol. 55, 233-262, 1988.

[6] Udensi, E. E., Osazuwa, I. B. Spectral determination of depths to magnetic rocks under the Nupe Basin, Nigeria, Nigeria Association of Petroleum Explorationists Bulletin, 17, 22-37, 2004.

[7] Krumbein, W.C. and Monk, G.D. Permeability a function of the size parameters of unconsolidated sands: Am. Inst. Min. Met Eng. Trans., Vol. 151, 153 - 162, 1942.

[8] Beard, D. C and Weyl, P. K. Influence of texture on porosity and permeability of unconsolidated sand, AAPG Bulletin, Vol. 57, No. 2, 348-369, 1973.

[9] Driscoll, F.G. Ground water and wells ( $2^{\text {nd }}$ edition). Johnson Div., St Paul, MN, 1089, 1986.

[10] Lambe, T. W. Soil testing for engineers: John Wiley and Sons, Inc., New York, 165, 1951.

[11] Fetter, C.W. Applied Hydrogeology (3rd edition). Prentice Hall, New Jersey, 691, 1994.

[12] Miall, A. D. A review of the braided river depositional environment, Earth Science Reviews, Vol. 13, 1-62, 1977a.

[13] Collinson, J. D. Alluvial sediments. In: Sedimentary Environments: Processes, Facies and Stratigraphy (Ed. Reading, H.G.), Blackwell Science, Oxford; 37-82, 1996.

[14] Devaney, J. R. Clastic Sedimentology of the Beaufort Formation, Prince Patrick Island, Canadian Arctic Islands: Late Tertiary Sandy Braided River Deposits with Woody Detritus Beds, The Arctic Institute of North America Vol. 4.4, No. 3, 206-216, 1991.

[15] Moore, J., Andrew T., Cari, J., Bradley D. R. and Rosalind, A. Facies analysis, reservoir characterization, and LIDAR modeling of an Eocene Lacustrine Delta, Green River formation, Southwest Uinta basin, Utah. In O. W. Baganz, Y. Bartov, K. Bohacs, and D. Nummedal, eds., Lacustrine sandstone reservoirs and hydrocarbon systems, AAPG Memoir 95,183-208, 2012.

[16] Nichols, G. Sedimentology and stratigraphy, Wiley-Blackwell publishing, UK, 2009.
[17] Boggs, S. Jr. Principles of Sedimentology and Stratigraphy. Prentice Hall, Englewood Cliffs, New Jersey, 2005.

[18] Ehrenberg, S. N. and Nadeau, P. H. Sandstone vs. carbonate petroleum reservoirs: A global perspective on porosity-depth and porosity-permeability relationships, AAPG Bulletin, Vol. 89, No. 4, 435-445, 2005.

[19] Sambrook-Smith, G. H., P. J. Ashworth, J. L. Best, J. Woodward and Simpson C. J. The alluvial architecture and sedimentology of the sandy, braided South Saskatchewan River, Canada, Sedimentology, Vol. 53, 413-434, 2006.

[20] Lunt, I. A., Sambrook-Smith, G. H., Best, J. L., Ashworth, P. J., Lane, S. N, and Simpson, C. J. Deposits of the sandy braided South Saskatchewan River: Implications for the use of modern analogs in reconstructing channel dimensions in reservoir characterization, AAPG Bulletin, Vol. 97, No. 4, 553-576, 2013.

[21] Bridge, J. S. and Tye, R. S. Interpreting the Dimensions of Ancient Fluvial Channel Bars, Channels, and Channel Belts from Wireline-Logs, AAPG Bulletin, Vol. 84, No. 8, 1205-1228, 2000.

[22] Cant, D. J. and Walker, R. G. Fluvial processes and facies sequences in the sandy braided South Saskatchewan River, Canada, Sedimentology, Vol. 25, 625-648, 1978.

[23] Smith, N.D. Some comments on terminology for bars in shallow rivers. In: Fluvial Sedimentology (Ed. A.D. Miall), Can. Soc. Petrol. Geol. Mem., 5, 85-88, 1978.

[24] Bridge, J. S. Rivers and floodplains: Forms, processes and sedimentary record, Blackwell, Malden, Massachusetts, 2003.

[25] Adeleye D. R. and Dessauvagie, T.F.J. Stratigraphy of the Middle Niger Embayment near Bida, Nigeria, African Geology, University of Ibadan press, 181-186, 1972.

[26] Braide, S.P. Alluvia Fan Depositional Model in the Northern Bida Basin, Jour. Min. Geol., Vol. 28, 65-73, 1992.

[27] Okosun, E. A., Goro, A. I., Olobaniyi, S. B., Shekwolo, P. D., and Nwosun, J. E. Stratigraphy of Bida Formation, Bida Basin, Nigeria, Borno Jornal of Geology, Vol. 4, 21-37, 2009.

[28] Kerr, D. R. and Jirik, L. A. Fluvial architecture and reservoir compartmentatlization in the Oligocene middle Frio Formation, south Texas: Gulf Coast Association of Geological Societies Transactions, Vol. 40, 373 - 380, 1990.

[29] Tucker, M.E. Sedimentary Rocks in the Field ( $3^{\text {rd }}$ edition). Wiley, Chichester. 2003.

[30] Adams, M. M. and Bhattacharya, J. P. No Change In Fluvial Style Across A Sequence Boundary, Cretaceous Blackhawk and Castlegate Formations of Central Utah, U.S.A., Journal of Sedimentary Research, Vol. 75, 1038-1051, 2005.

[31] Ashworth, P. j., Sambrook-Smith, G. H., Best, J. L., Bridge, J.S., Lane, S. N., Lunt, I. A., Reesink, A. J. H., Simpson, C. J. and Thomas, Robert E. Evolution and sedimentology of a channel fill in the sandy braided South Saskatchewan River and its comparison to the deposits of an adjacent compound bar, Sedimentology, Vol. 58, No. 7, 1860-1883, 2011. 